\title{
A preliminary molecular and morphological phylogeny of the Antarctic Epimeriidae and Iphimediidae (Crustacea, Amphipoda)
}

\author{
Anne-Nina Lörz ${ }^{\mathrm{a}, *}$ and Christoph Held ${ }^{\mathrm{b}}$ \\ ${ }^{a}$ National Institute of Water and Atmospheric Research, P.O. Box 14-901 Kilbirnie, Wellington, New Zealand \\ ${ }^{\mathrm{b}}$ Ruhr-University Bochum, Universitätsstrasse 150, D-44780 Bochum, Germany
}

Received 18 October 2002; revised 6 July 2003

\begin{abstract}
The phylogenetic relationships of 14 species of the Antarctic amphipod families Epimeriidae and Iphimediidae were investigated using $553 \mathrm{bp}$ of the gene for the mitochondrial cytochrome oxidase subunit I (COI) and 98 morphological characters. Both families are dominant members of the Antarctic benthic amphipod community. In contrast to previous studies, our molecular and morphological data suggest that the families Epimeriidae and Iphimediidae may not be sister taxa. Our study suggests that Iphimediidae are more closely related to Eusirus (Eusiridae) than to Epimeria (Epimeriidae). Phylogenetic analyses based on maximum parsimony (MP) and maximum likelihood (ML) indicate that the genera Iphimediella and Gnathiphimedia are not monophyletic.

(C) 2003 Elsevier Inc. All rights reserved.
\end{abstract}

Keywords: Antarctica; Benthic amphipods; Cytochrome oxidase I; Cladistics; Eusiridae; Epimeriidae; Iphimediidae

\section{Introduction}

The families Epimeriidae and Iphimediidae are dominant members of the Antarctic benthic amphipod community (Coleman, 1996; De Broyer et al., 2001). Both families occur worldwide although their main occurrence is in polar waters. Currently 25 species in six genera of Epimeriidae are known from the Southern Ocean, 17 of them from the genus Epimeria. The Iphimediidae consist of 48 species belonging to 13 genera. Both families are found throughout the Antarctic. Epimeriidae as well as Iphimediidae belong to the superfamily Iphimedoidea, also including, e.g., Dikwidae, Ochlesidae, Odiidae, and Acanthonotozomellidae.

Very little is known about the evolution and phylogeny of these two families. Watling and Thurston (1989) considered the Epimeriidae (former Paramphithoidae Stebbing 1906) as the sister taxon to the Iphimediidae, but the cladistic biogeography of Antarctic Iphimediidae was based on only six morphological characters. In addition the relatively small

\footnotetext{
${ }^{*}$ Corresponding author.

E-mail address: a.loerz@niwa.co.nz (A.-N. Lörz).
}

phylogenetic analysis, which was carried out before programs such as PAUP were readily available, has proved to be a powerful tool for biogeography. These authors suggested that the retraction of species from a former cosmopolitan distribution occurred before the thermal isolation of Antarctica.

This present study, presents the first molecular analysis of phylogeny of a subset of Antarctic Epimeriidae and Iphimediidae. It is not intended to represent a complete phylogeny of the two families because the number of species from previous expeditions was limited due to formaldehyde fixation of specimens. The Epimeriidae are represented by six species of Epimeria, while the Iphimediidae genera Echiniphimedia, Gnathiphimedia, and Iphimediella are represented by a total of eight species. The phylogenetic analysis presented here used morphological and mtDNA evidence, testing them for congruence.

For molecular study a mitochondrial DNA region was chosen to provide resolution at the intergeneric level. Among the mitochondrial genes investigated in Crustacea, the cytochrome oxidase I subunit (COI) gene has proved to be a very useful taxonomic and phylogenetic marker at the intergeneric level (e.g., Meyran et al., 1997; Wares, 2001). 
The molecular study is compared with a phylogenetic approach based on morphological characters.

\section{Material and methods}

Amphipods were collected during the cruise ANT XVII-3 by the RV "Polarstern" (Arntz and Brey, 2001). The animals were hand-sorted from towed gear (bottom trawl and Rauschert dredge). In order to minimize degradation of DNA, live animals were briefly rinsed with pre-chilled freshwater and preserved in $96 \%$ ethanol at $-30^{\circ} \mathrm{C}$ (following Held, 2000). Muscle tissue of the first pleopods was isolated while keeping the animals on ice. The tissue was kept refrigerated in $96 \%$ ethanol until DNA extraction took place. Species names, sampling locality and depth, as well as accession numbers and collection numbers in the Zoological Institute and Zoological Museum Hamburg are listed in Appendix A.

Eusirus cf. perdentatus (Eusiridae) and Monoculodes sp. (Oedicerotidae) were chosen as outgroups for the analysis of morphological characters. While Eusirus is considered to be closely related to Epimeriidae and Iphimediidae (Englisch, 2001), the Oedicerotidae are believed to be distantly related to Epimeriidae or Iphimediidae (Berge et al., 2001). Specimens of the morphological outgroup species were collected on the same cruise and treated the same way as the epimeriid and iphimediid specimens.

For molecular analyses, five additional outgroup sequences were obtained from GenBank. The genera Scopelocheirus and Hirondellea belong to the family Lysianassidae whereas Pontogammarus, Euxinia, and Obesogammarus are members of the family Gammaridae.

Two morphological and five molecular outgroup taxa were chosen because multiple outgroup taxa can increase resolution and support for basal ingroup nodes (Maddison et al., 1984).

\subsection{DNA amplification and sequencing}

Genomic DNA was isolated using the method of Held (2000) from small pieces of muscle tissue using a QIAamp DNA Mini Kit. PCRs were carried out in 50- $\mu 1$ volumes; with $2 \mathrm{U}$ Qiagen $T a q$ polymerase, $5 \mu \mathrm{l}$ $10 \times$ PCR buffer including $1.5 \mathrm{mM} \mathrm{MgCl}_{2}, 250 \mu \mathrm{M}$ of each dNTP, 60 pmol of each amplification primer, and $0.5-1.2 \mu 1$ DNA template. Sterile water was added to a total of $50 \mu \mathrm{l}$. The COI fragment was amplified using primer sequences developed by Folmer et al. (1994). For amplification modified versions of the primers carrying a sequence tag on their $5^{\prime}$ tails were used (Held, 2003): HCO 5'-AGC GGA TAA CAA TTT CAC ACA GGT AAA CTT CAG GGT GAC CAA AAA ATC- ${ }^{\prime}$ and LCO 5'-CCC AGT CAC GAC GTT GTA AAA CGG
TCA ACA AAT CAT AAA GAT ATT GG-3', both primers were provided by MWG-Biotech $\mathrm{GmBH}$. The amplification profile was $3 \mathrm{~min}$ at $94{ }^{\circ} \mathrm{C}$ for denaturation, 36 cycles of $1 \mathrm{~min}$ at $94^{\circ} \mathrm{C}, 1 \mathrm{~min}$ at $42^{\circ} \mathrm{C}, 1.5 \mathrm{~min}$ at $72^{\circ} \mathrm{C}$, and last $7 \mathrm{~min}$ at $72^{\circ} \mathrm{C}$ for final extension.

PCR products were purified with Qiagen spin columns (PCR purification kit) and run on an $1 \%$ ethidium bromide stained agarose minigel to evaluate purity and DNA content. Purified PCR product $(1-3 \mu 1)$ was used for dideoxy cycle sequencing using the manufacturer's protocols (Amersham and Biozym). The sequencing amplification protocol was $94^{\circ} \mathrm{C}$ for $2 \mathrm{~min}, 30$ cycles of $94^{\circ} \mathrm{C}$ for $25 \mathrm{~s}, 52^{\circ} \mathrm{C}$ for $25 \mathrm{~s}$, and $70^{\circ} \mathrm{C}$ for $35 \mathrm{~s}$ and stored at $4{ }^{\circ} \mathrm{C}$.

For sequencing the COI amplification products the fluorescent labelled primers PFS: $5^{\prime}$-CCC AGT CAC GAC GTT GTA AAA C- $3^{\prime}$ and PRS: $5^{\prime}$-AGC GGA TAA CAA TTT CAC ACA GG- $3^{\prime}$ were used. Depending on the concentration of the COI amplification products $0.5-3 \mu \mathrm{l}$ of the cycle sequencing reaction was loaded onto an automated sequencer (Li-Cor, models 4000 and 4200).

Gels were proofread using the image analysis software of the automated sequencer. Double stranded sequences were assembled with AlignIR v1.2.

\subsection{Phylogenetic analysis}

The proof-read sequences of the 16 species were aligned with Clustal W version 1.4 (Thompson et al., 1994) as included in BioEdit (Hall, 1999) using default parameters. The alignment was truncated to avoid excessive gaps at either end of the alignment. Minor corrections of the alignment were carried out in order to preserve a contiguous reading frame. One indel of serine occurred in five species of Iphimediidae which will be discussed below.

After exclusion of uninformative positions (Cunningham, 1997), an incongruence length difference test as implemented in PAUP was performed in order to test the combinability of different codon positions (codon positions 1 and 2 versus position 3). This test was repeated using different weighting schemes for transition/ transversion substitutions.

Phylogenetic trees under the maximum parsimony (MP) optimality criterion were inferred using PAUP 4.10 beta (Swofford, 2002). $\chi^{2}$ tests of homogeneity of base frequencies were also calculated in PAUP. The effect of different weighting schemes of substitution types and codon positions on the inferred tree topology was tested. Bootstrap tests with 1000 replicates were used to assess support of various phylogenetic groups.

Trees under the maximum likelihood (ML) optimality criterion were calculated using Paup 4b10, MrBayes 3.0 (Huelsenbeck and Ronquist, 2001) and for protein data also Tree-Puzzle 5.0 (Strimmer and von Haeseler, 
1996). Models of sequence change over time were chosen based on a hierarchical likelihood ratio test (LRT) (Huelsenbeck and Crandall, 1997) as implemented in Modeltest version 3.06 (Posada and Crandall, 1998). This model was then used to calculate pairwise genetic distances and the ML tree.

Bayesian inference of phylogeny was carried out running four parallel chains in MrBayes3.0 for 100,000 generations, sampling trees every 100 generations. Six substitution types were allowed corresponding to the GTR model. Site specific rates were used, unlinking rate estimation of the third codon position from the rate estimate for the first two codon positions. The log likelihood reached stationarity after 5000 generations thus 50 trees were discarded as the "burnin."

For maximum likelihood analysis of protein data, the model proposed for mitochondrial genes proposed by Adachi and Hasegawa (1996) was used with gamma distributed rates.

All morphological characters coded in the matrix were examined on several individuals of each species deposited in the Zoological Museum Hamburg and through descriptions in the literature. One specimen of Iphimediella georgei Watling and Holman, 1980 was borrowed from the Museum für Naturkunde in Berlin, Germany. A database of 98 morphological characters was assembled using the software DELTA (Dallwitz et al., 1997). We primarily used binary rather than multistate characters (Appendix B). A data matrix (nexus file) was generated for input in PAUP 4.10 beta. All characters were unordered and treated as having equal weight. The list of characters is presented in Appendix $\mathrm{B}$, the matrix is shown in Appendix C.

\section{Results}

\subsection{Analysis of the nucleotide sequences}

Among the remaining 553 aligned nucleotide sites in the mitochondrial COI gene fragment, 302 are variable of which 274 bases are parsimony-informative including the outgroup species (284 and $257 \mathrm{bp}$ for the ingroup, respectively). As expected the majority of variable sites occurred in the third codon position (171 out of $274 \mathrm{bp}$ ).

When all taxa were included, their base composition was found to be significantly different $(p=0.01893)$. There was insufficient evidence for base composition differences, however, when the most divergent sequence (Monoculodes) was excluded ( $p=0.2005)$.

A partition-homogeneity test revealed significant differences between first and second versus third codon positions $(p=0.02)$, whereas no significant difference was found between first and second codon positions $(p=0.98)$. This difference dissapeared when only ingroup sequences were compared $(p=0.62)$. For this reason all third codon positions were re-coded as missing information in the outgroup whereas they were retained for the ingroup. The rooting of the tree was thus based on the more conserved first two codon positions while the third codon position still contributes to the relation within the ingroup species (Whiting, 2002).

A heuristic search found a single most parsimonious tree when transitions and transversions are weighted equally (length 959 steps, $\mathrm{CI}=0.5193, \mathrm{RI}=0.6174$, $\mathrm{RC}=0.3206$ ).

Applying different weighting schemes for codon positions and substitution types mostly affected the branching pattern in the outgroup which is outside the scope of this paper.

Some points regarding the ingroup relationships are worth mentioning:

A sistergroup relationship between $E$. hodgsoni and E. echinata is parismonious only when substitution types and codon positions are weighted equally ( $\mathrm{t} i=\mathrm{tv}$, codon weighting 111). When either transitions or third codon positions are downweighted, a sistergroup relation between E. hodgsoni and E. waegeli is favoured (see Figs. 1 and 2).

Similarly, the resolution between Epimeria reoproi, Epimeria similis, and Epimeria macrodonta is ambiguous when equal weighting is applied. When transitions or third codon positions are downweighted, a sistergroup relationship between E. reoproi and E. macrodonta becomes more parsimonious.

Equal weighting results in ambiguous support concerning the relationship of Iphimediella cyclogena and the two Gnathiphimedia species. Downweighting transitions and third codon positions consistently groups them as in Fig. 4. Taking into account the high variability of the third codon position, the nodes that can only be obtained with equal weighting of substitution types are considered unreliable and therefore a tree based on a weighted analysis is preferred. Trees based on various weighting combinations can be made available by the second author.

The LRT revealed the TvM model with gamma distributed rates $($ alpha $=0.8611)$ and invariant sites (pin$\operatorname{var}=0.4175$ ) as the model with the best fit to the data. The ML tree is identical to the MP tree inside the Epimeriidae and Iphimediidae and with only insignificant variation in the placement among some outgroup sequences (Shimodaira-Hasegawa test, $p>0.20$ ).

\subsection{Analysis of the amino acid sequences}

No conflicting signal can be identified between the protein and DNA data partitions under standard maximum parsimony (partition-homogeneity test, $p=0.93$ ). Of 185 amino acids only 56 were parsimony-informative (tree length $=159, \mathrm{CI}=0.824, \mathrm{RI}=0.885, \mathrm{RC}=0.729$ ). The ML tree based on the Adachi and Hasegawa (1996) 


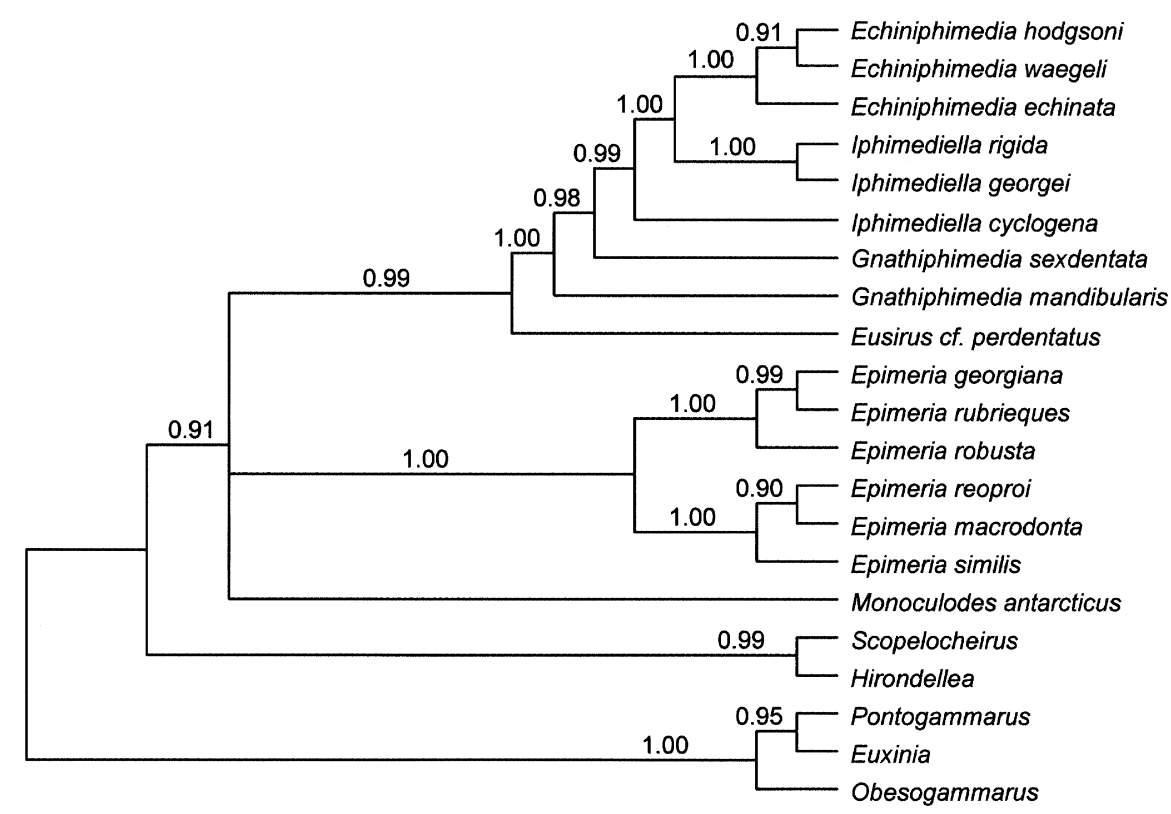

Fig. 1. Bayesian inference of phylogenetic relations based on $553 \mathrm{bp}$ of the COI gene. Bayesian support values are indicated on the branches. Six substitution types with gamma distributes rates and rate estimates for the third codon position unlinked from the first two codon positions.

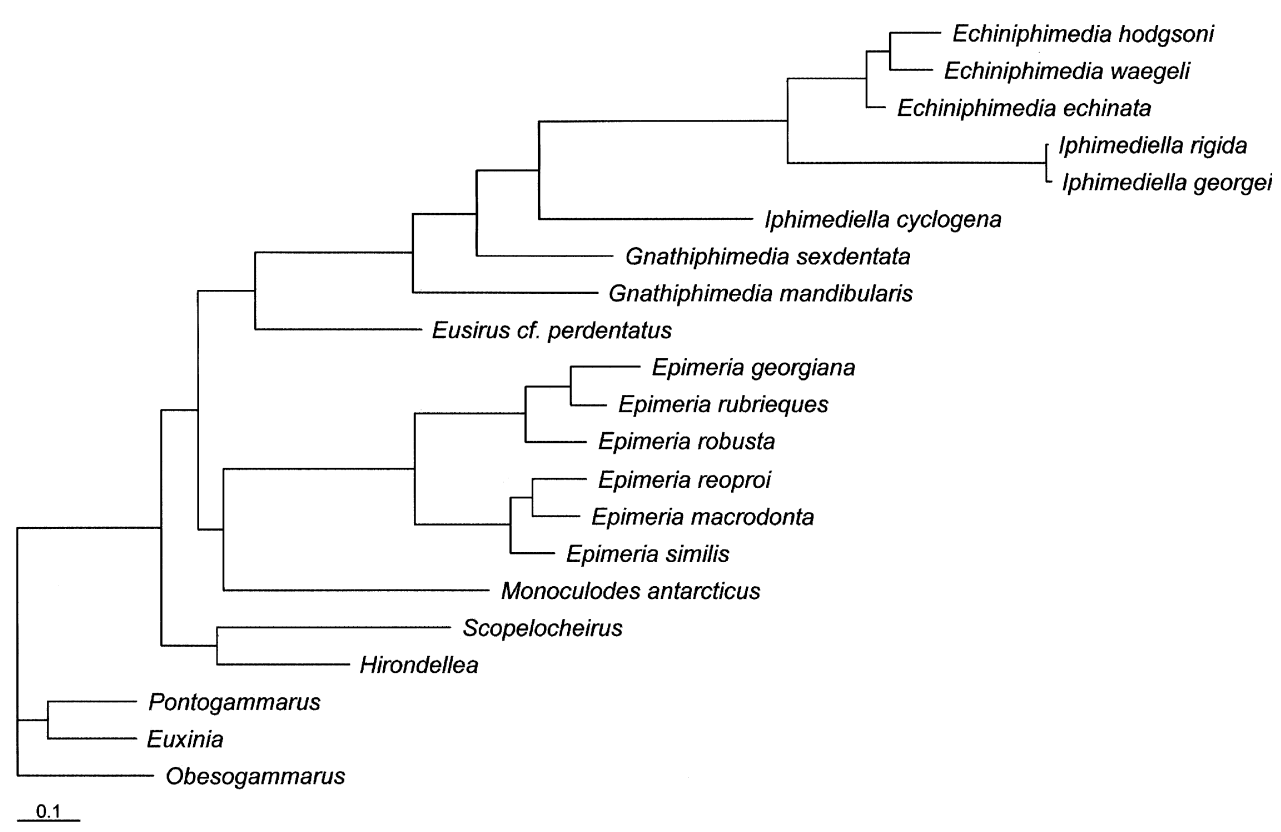

Fig. 2. Maximum likelihood (ML) phylogram based on 553 nucleotides from the COI gene. Model choice based on a hierarchical LRT (six subsitution types with gamma distributed rates $($ alpha $=0.8611)$ and invariant positions (pinvar $=0.4175)$. A heuristic search with random addition of taxa (5 replicates each) and TBR branch swapping was conducted.

model for mitochondrially encoded genes is less well resolved than the ML tree based on nucleotide data of the same gene fragment with the subtrees for Iphimediidae and Epimeriidae being compatible with the tree inferred from DNA data (Fig. 3). Conflicting resolution between the ML trees based on DNA and protein data is confined to the outgroup (SH test, $p<0.05$ ).

\subsection{Analysis of the morphological characters}

The tree for the morphological characters was rooted with Monoculodes based on its position in the molecular tree. The branch-and-bound search using unweighted characters resulted in one tree (tree length $=205$, $\mathrm{CI}=0.532, \mathrm{RI}=0.713, \mathrm{RC}=0.379$ ), Fig. 5. Of 98 


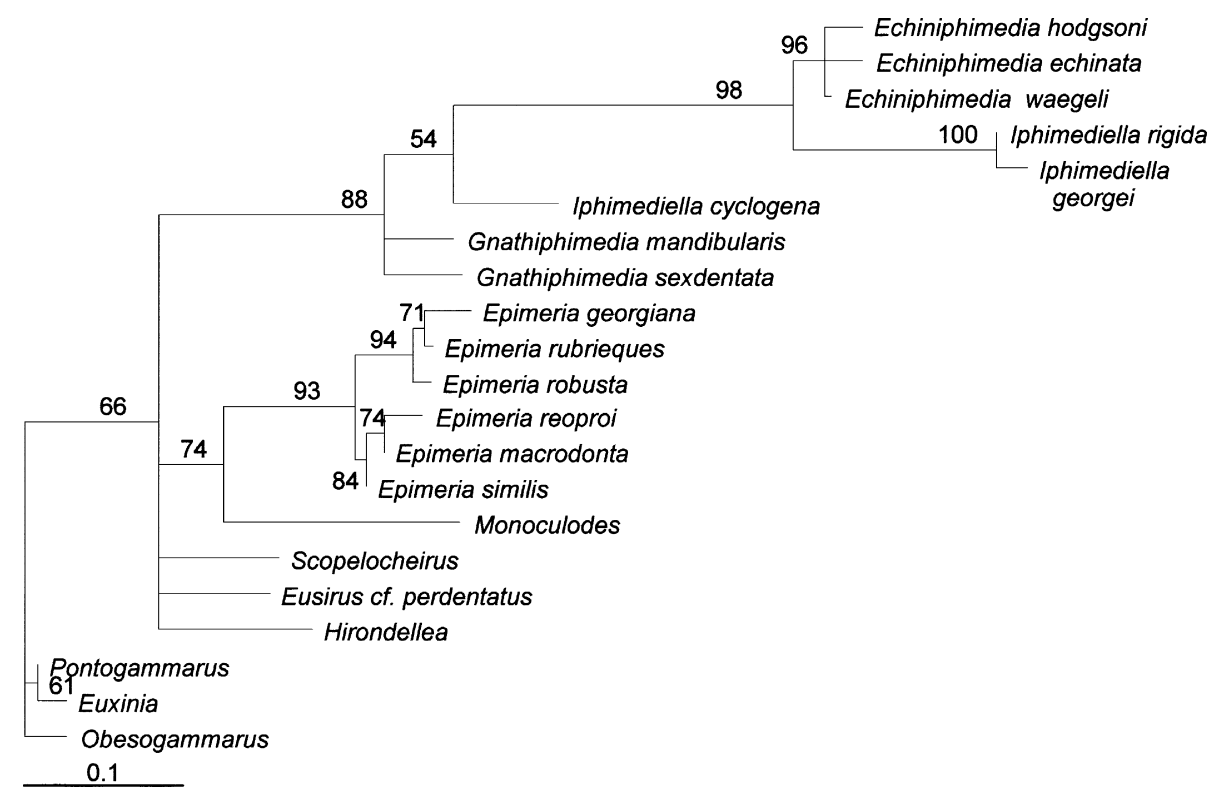

Fig. 3. An ML estimate of the phylogeny of 14 species of Antarctic Epimeriidae and Iphimediidae based on 185 aminoacids. The mtREV24 model for mitochondrially encoded genes was used with gamma distributed rates (Adachi and Hasegawa, 1996). Shape parameter estimated from the dataset (alpha $=0.27)$.

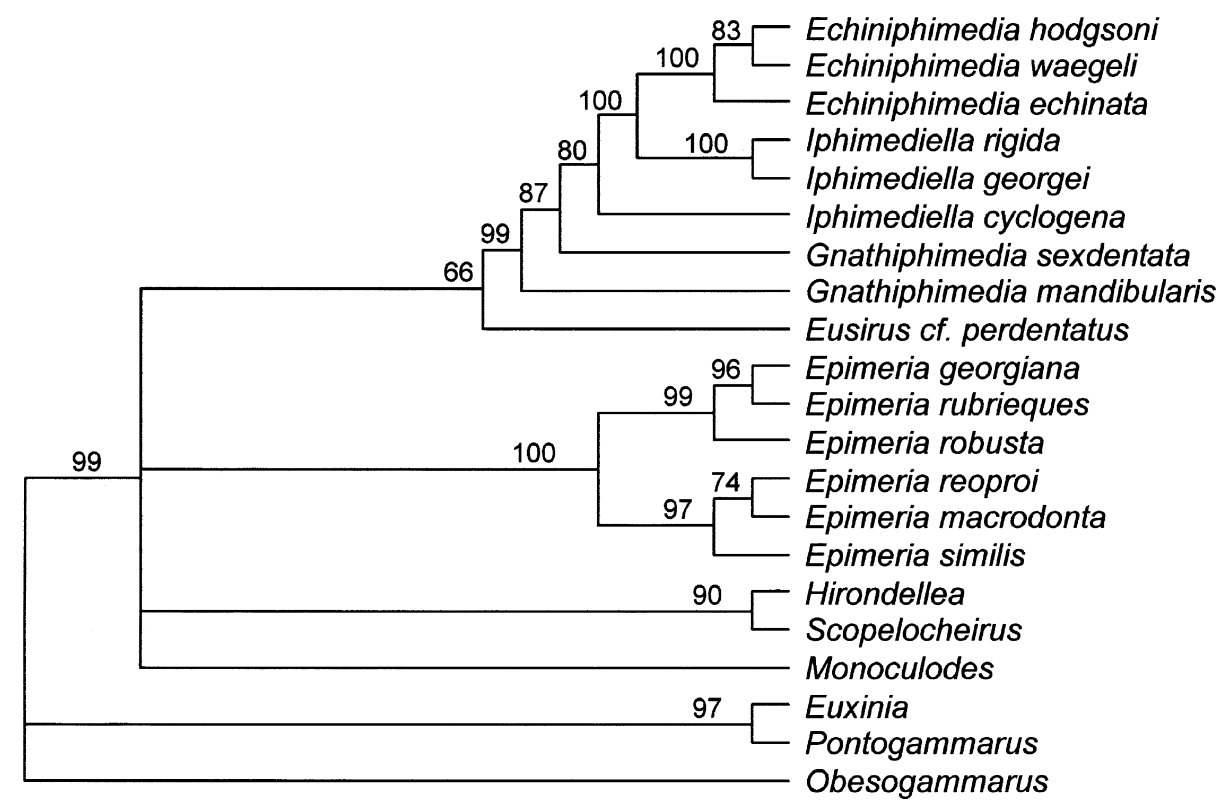

Fig. 4. Maximum parsimony (MP) 50\% majority rule consensus tree. Numbers on branches are bootstrap values of 1000 replicates (higher than $50 \%$ shown). Third codon positions are downweighted by factor 3 and transversions are weighted 3 times over transitions. Third codon positions for the outgroup species and gaps are treated as missing information (see text for details).

unordered characters 9 are constant and 6 are parsimony-uninformative, 83 characters are parsimony-informative.

The tree based on morphological characters differs significantly from those based on the COI fragment ( $\mathrm{SH}$ test, $p<0.05)$.
There is little doubt that Gnathiphimedia is paraphyletic with the two included representatives branching off sequentially at the base of the Iphimediidae subtree.

In no analysis the two families Iphimediidae and Epimeriidae are sistergroups. Instead, at least one of the outgroup sequences (Eusirus cf. perdentatus) 


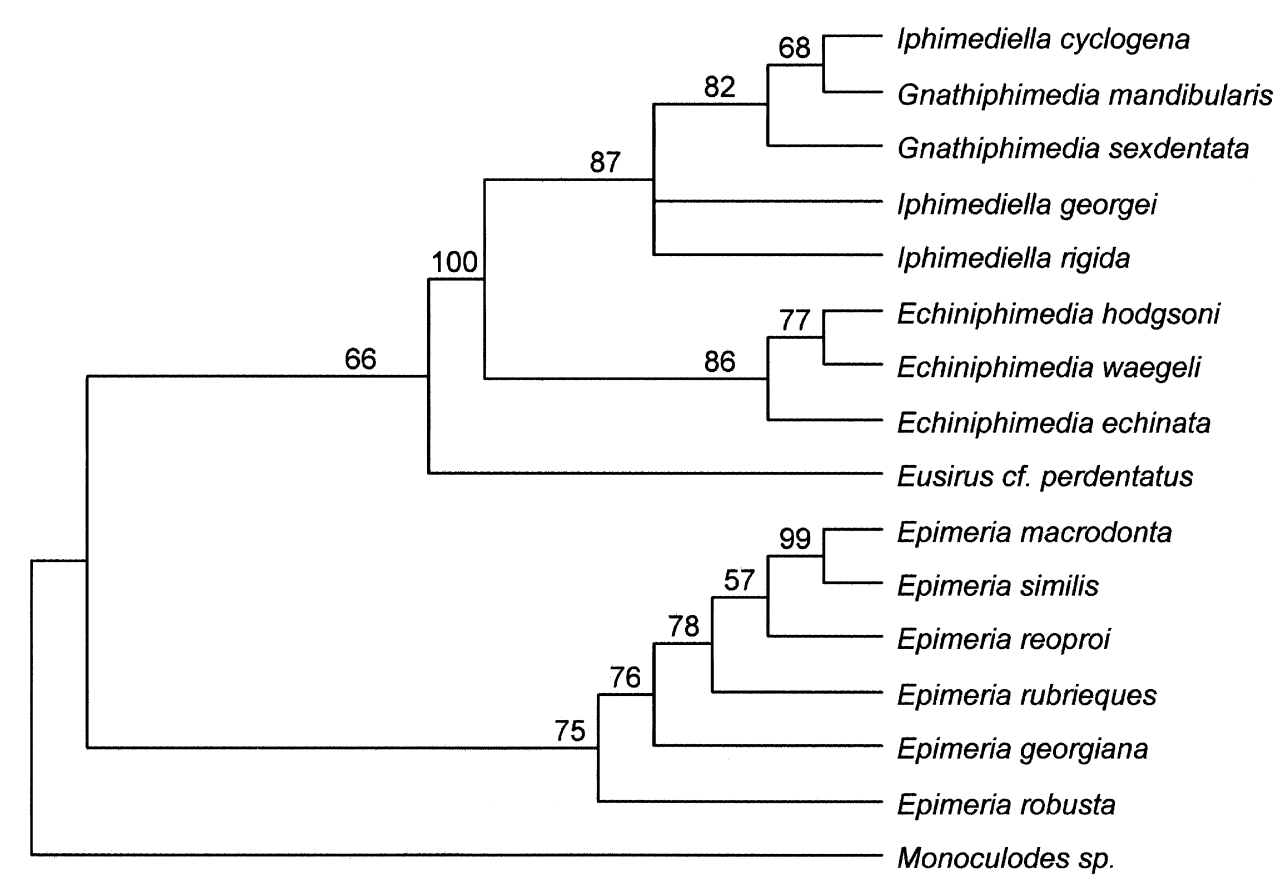

Fig. 5. Phylogenetic tree of 16 Antarctic Amphipoda based on 83 phylogenetic informative morphological characters, bootstrap values of 1000 replicates higher than 50\% shown. For five species taken from GenBank no morphological information was available.

clustered consistently as sister to the Iphimediidae, in some analyses Monoculodes was sister to the Epimeriidae. Our analysis therefore provides no evidence of Epimeriidae and Iphimediidae being sister taxa as stated by Watling and Thurston (1989).

\section{Discussion}

Although only a relative small number of taxa were used in this study, our results show that analysis of the $\mathrm{COI}$ sequence is suitable for revealing differences at the interspecific level and family level for two Antarctic amphipod families. The higher classification of iphimedioid amphipods has frequently been revised in recent years (Berge et al., 1998; Coleman and Barnard, 1991; Watling and Thurston, 1989). The magnitude of the genetic differences observed between species of Epimeria and between species of Iphimediidae is not correlated with spatial differentiation. According to the zoogeographical zonation of the Southern Ocean (De Broyer and Jazdzewski, 1993), the outgroup taxa used in this analysis (Eusirus cf. perdentatus, Monoculodes sp.) and Epimeria georgiana and E. reoproi are from West Antarctica, while all the other species are from the East Antarctic. Since the two West Antarctic species showed the highest nucleotide divergence within the species of Epimeria, the geographic distance apparently does not influence the genetic differentiation.

All analyses indicated the monophyly of Epimeria and the Iphimediidae included in this study, supported by a bootstrap values of over 90 at the basal branch. There is a strongly supported monophylum consisting of all Echiniphimedia species and two of the three Iphimediella species. This clade lacks three nucleotides coding for the aminoacid serine that are uniformly present in all other species in this study including all outgroup sequences. The absence of this serine is therefore most likely a deletion which occurred in the most recent ancestor of Echiniphimedia and Iphimediella rigida and I. georgei. The genus Iphimediella in its current state is therefore clearly paraphyletic as Iphimediella cyclogena lacks this apomorphic deletion.

One of our aims was to gain an independent assessment of morphological and molecular characteristics that are thought to be of phylogenetic importance. Our molecular and morphological analyses result in phylogenies of the tested species that provide some new insights into character evolution that partly contradict previous interpretations (e.g., Watling and Thurston, 1989). Some characters and difficulties are discussed in more detail below.

Coleman and Barnard (1991) defined two characters for differentiation between the families Epimeriidae and Iphimediidae; the Iphimediidae do not have raker spines, but possess at least one pair of chelate gnathopods. Upon examination of 14 species of these families only certain characters turned out to be restricted to the family Iphimediidae or the genus Epimeria. Only Epimeria bear spines on the inner curvature of the dactyli of their gnathopods. The examined iphimediids as well as Eusirus cf. perdentatus have pointed posteroventral corners of 
pereonite 5 and 6 while those of the examined Epimeria are rounded. The posteroventral corner of pereopod 7 is also pointed in Epimeria, except in E. robusta.

Referring to the compared mitochondrial sequences Epimeria georgiana, E. rubrieques, and E. robusta form a monophyletic clade. In contrast these taxa seem to be paraphyletic when comparing the morphological characters. In the present analysis all morphological characters have the same weight. Of the six Epimeria species studied only E. georgiana, E. rubrieques, and E. robusta have produced and pointed posteroventral angles on the basis of pereopods 5-7 (characters 55 and 56, see Appendix B). Most likely this morphological feature proves to be phylogenetically more informative than others tested in this study.

The monophyly of Iphimediella is questionable because characters such as the incisor show both toothed (I. georgiana, I. rigida) and smooth states (I. cyclogena). I. cyclogena, which bears a smooth incisor, clades with the genus Gnathiphimedia, which also bears a smooth incisor. In addition Gnathiphimedia and Iphimediella both have paired teeth on pereonite 7 .

One main character used in species keys of Epimeria is the presence of dorsal carinae on the pereon (e.g., Wakabara and Serejo, 1999). This obvious character is not supported by our molecular analyses, since $E$. robusta with all pereon segments lacking dorsal carinae, appears to be closely related to E. rubrieques (Fig. 1), a species with carinae on all pereon segments. A morphological character shared by E. robusta and E. georgiana is the sharply notched basis of pereopod 5 .

In view of the size of the molecular dataset the differences between the trees inferred from molecular and morphological data should not be overinterpreted.

\subsection{Speciaton times}

Wares (2001) estimated the substitution rate of the same region of COI for Cirripedia 3.1 percent divergence per million years under the general time reversible model. The two monophyletic groups within the genus Epimeria are separated by a mean genetic distance of 0.4891 . When using the cirriped rate of substitution in this gene fragement the last common ancestor of the Epimeria species in this study can be estimated to have lived approximately 15.7 million years ago. Since the cooling of Antarctica took place about 40 million years ago (Crame, 1999) the divergence between Epimerias occurred after the cooling of the Southern Ocean. Even when the most conservative rate estimate for the corresponding fragment of the COI gene is applied (Knowlton and Weigt, 1998), the estimated age of the most recent common ancestor for the Epimeria spp. increases to 34.9 milllion years.

Similarly, all iphimediid species which are related through the supposedly oldest node in Fig. 2 are separated by an average distance around 1.0043 under the TvM model from Gnathiphimedia mandibularis. The inferred age of the last common ancestor of the iphimediid species is thus 34.4 million years using the cirriped rate, only when the snapping shrimp rate is applied this estimate increases to 71.7 million years.

The timeline of speciation as well as the endemicity to Antarctic waters are consistent with the view that the epimeriid and potentially also the iphimediid species in this study evolved in the Southern Ocean when it was already isolated from other fragments of Gondwanaland and cold.

\section{Acknowledgments}

Thanks are due to A. Brandt, J.-W. Wägele, K. Linse, and S. Gerken for helpful advice. During the cruise ANT XVII-3 following colleagues especially helped sorting the material: O. Ziemer, M. Schrödl, J. Bohn, and M. Rauschert. C.O. Coleman checked the determination of the amphipod species and kindly lent us specimens from the collection of the Museum für Naturkunde in Berlin. B. Hackethal is thanked for her technical assistance. Thanks are also due to U. Englisch for helpful discussions. This article is based on a doctoral study by AnneNina Lörz in the faculty of Biology, University of Hamburg, supported by the Studienstiftung des deutschen Volkes and by a grant to A. Brandt from the Deutsche Forschungsgemeinschaft (Br 1121/18-1).

\section{Appendix A}

Species, availability of sequences, collection localities, and specimen-deposition number of the Zoological Institute and Zoological Museum Hamburg (ZIM) and five outgroups (Lysianassidae and Gammaridae) from the GenBank

\begin{tabular}{|c|c|c|c|c|c|}
\hline Taxa & $\begin{array}{l}\text { Sequence } \\
\text { Accession No. }\end{array}$ & Depth (m) & Latitude & Longitude & $\begin{array}{l}\text { ZIM collection } \\
\text { number }\end{array}$ \\
\hline
\end{tabular}

Epimeriidae

Epimeria georgiana

Schellenberg, 1931

Epimeria reoproi Lörz and

Coleman, 2001

$\begin{array}{llll}\text { AF451341 } 202 & 62^{\circ} 49.50^{\prime} \mathrm{S} & 060^{\circ} 49.30^{\prime} \mathrm{W} \quad 39888\end{array}$

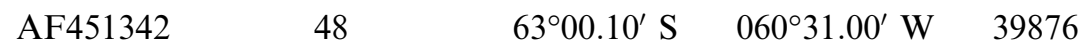


Appendix A (continued)

\begin{tabular}{|c|c|c|c|c|c|}
\hline Taxa & $\begin{array}{l}\text { Sequence } \\
\text { Accession No. }\end{array}$ & Depth (m) & Latitude & Longitude & $\begin{array}{l}\text { ZIM collection } \\
\text { number }\end{array}$ \\
\hline $\begin{array}{l}\text { Epimeria robusta } \\
\text { K.H. Barnard, } 1930\end{array}$ & AF451344 & 323 & $71^{\circ} 11.90^{\prime} \mathrm{S}$ & $012^{\circ} 21.70^{\prime} \mathrm{W}$ & 39902 \\
\hline $\begin{array}{l}\text { Epimeria macrodonta } \\
\text { Walker, } 1906\end{array}$ & AF451343 & 316 & $71^{\circ} 11.90^{\prime} \mathrm{S}$ & $012^{\circ} 20.70^{\prime} \mathrm{W}$ & 39889 \\
\hline $\begin{array}{l}\text { Epimeria rubrieques } \\
\text { De Broyer and Klages, } 1991\end{array}$ & AF451345 & 648 & $71^{\circ} 16.67^{\prime} \mathrm{S}$ & $013^{\circ} 45.79^{\prime} \mathrm{W}$ & 39890 \\
\hline $\begin{array}{l}\text { Epimeria similis } \\
\quad \text { Chevreux, } 1912\end{array}$ & AF451346 & 648 & $71^{\circ} 16.67^{\prime} \mathrm{S}$ & $013^{\circ} 45.79^{\prime} \mathrm{W}$ & 39891 \\
\hline Iphimediidae & & & & & \\
\hline $\begin{array}{l}\text { Iphimediella georgei } \\
\text { Watling and Holman, } 1980\end{array}$ & AF451349 & 316 & $71^{\circ} 11.90^{\prime} \mathrm{S}$ & $012^{\circ} 20.70^{\prime} \mathrm{W}$ & 39892 \\
\hline $\begin{array}{l}\text { Iphimediella rigida } \\
\text { K.H. Barnard, } 1930\end{array}$ & AF451347 & 323 & $71^{\circ} 11.90^{\prime} \mathrm{S}$ & $012^{\circ} 21.70^{\prime} \mathrm{W}$ & 39893 \\
\hline $\begin{array}{l}\text { Iphimediella cyclogena } \\
\text { K.H. Barnard, } 1930\end{array}$ & AF451348 & 323 & $71^{\circ} 11.90^{\prime} \mathrm{S}$ & $012^{\circ} 21.70^{\prime} \mathrm{W}$ & 39894 \\
\hline $\begin{array}{l}\text { Eciniphimedia echinata } \\
\text { Walker, } 1906\end{array}$ & AF451352 & 266 & $70^{\circ} 50.40^{\prime} \mathrm{S}$ & $010^{\circ} 35.20^{\prime} \mathrm{W}$ & 39895 \\
\hline $\begin{array}{l}\text { Echiniphimedia hodgsoni } \\
\quad \text { Walker, } 1906\end{array}$ & AF451350 & 323 & $71^{\circ} 11.90^{\prime} \mathrm{S}$ & $012^{\circ} 21.70^{\prime} \mathrm{W}$ & 39896 \\
\hline $\begin{array}{l}\text { Echiniphimedia waegeli } \\
\text { Coleman and Andres, } 1988\end{array}$ & AF451351 & 266 & $70^{\circ} 50.40^{\prime} \mathrm{S}$ & $010^{\circ} 35.20^{\prime} \mathrm{W}$ & 39897 \\
\hline $\begin{array}{l}\text { Gnathiphimedia mandibularis } \\
\text { K.H. Barnard, } 1930\end{array}$ & AF451353 & 269 & $70^{\circ} 50.20^{\prime} \mathrm{S}$ & $010^{\circ} 34.89^{\prime} \mathrm{W}$ & 39898 \\
\hline $\begin{array}{l}\text { Gnathiphimedia sexdentata } \\
\text { (Schellenberg, 1926) }\end{array}$ & AF451354 & 318 & $71^{\circ} 12.19^{\prime} \mathrm{S}$ & $012^{\circ} 19.01^{\prime} \mathrm{W}$ & 39899 \\
\hline $\begin{array}{l}\text { Eusiridae } \\
\text { Eusirus cf. perdentatus } \\
\quad \text { Chevreux, } 1912\end{array}$ & AF451355 & 673 & $63^{\circ} 01.20^{\prime} \mathrm{S}$ & $059^{\circ} 09.20^{\prime} \mathrm{W}$ & 39900 \\
\hline $\begin{array}{l}\text { Oedicerotidae } \\
\text { Monoculodes sp. }\end{array}$ & AF451356 & 48 & $63^{\circ} 00.10^{\prime} \mathrm{s}$ & $060^{\circ} 31.00^{\prime} \mathrm{W}$ & 39901 \\
\hline $\begin{array}{l}\text { Lysianassidae } \\
\text { Scopelocheirus schellenbergi } \\
\text { Hirondellea dubia }\end{array}$ & $\begin{array}{l}\text { AY256968 } \\
\text { AY183359 }\end{array}$ & & & & \\
\hline $\begin{array}{l}\text { Gammaridae } \\
\text { Pontogammarus robustoides } \\
\text { Euxinia maeoticus } \\
\text { Obesogammarus crassus }\end{array}$ & $\begin{array}{l}\text { AY189523 } \\
\text { AY189504 } \\
\text { AY189482 }\end{array}$ & & & & \\
\hline
\end{tabular}

\section{Appendix B}

Character list for the morphological analysis of 16 Antarctic Amphipoda

1. Telson apically: (1) rounded; (2) pointed

2. Telson, setae on lobe: (1) absent; (2) present

3. Telson excavation: (1) wide, shallow or absent; (2) narrow

4. Telson: (1) entire or cleft u-shaped; (2) cleft v-shaped

5. Telson elongation: (1) absent; (2) present (clearly longer than broad)

6. Uropod 3 outer ramus: (1) at least twice the length of peduncle; (2) less than twice the length of peduncle

7. Uropod 3 pointed process on apical margin: (1) absent; (2) present 


\section{Appendix B (continued)}

8. Uropod 2 outer ramus: (1) same length or longer than peduncle; (2) shorter than peduncle

9. Uropod louter ramus: (1) same length or longer than peduncle; (2) shorter than peduncle

10. Urosomit 1 dorsally: (1) smooth; (2) small projection; (3) long pointed projection; (4) multidentate carinae

11. Urosomite 1: (1) longer than urosomites 2 and 3 comined; (2) shorter than urosomites 2 and 3 combined

12. Urosomites 2 and 3 dorsally: (1) smooth; (2) articulated 13. Urosomite 1 posterolateral margin pointed process: (1) absent; (2) present

14. Urosomite 2 posterolateral margin pointed process: (1) absent; (2) present

15. Urosomite 3 posterolateral margin pointed process: (1) absent; (2) present

16. Urosomite 1 middorsal keel: (1) absent; (2) present

17. Urosomite 2 middorsal keel: (1) absent; (2) present

18. Urosomite 3 middorsal keel: (1) absent; (2) present

19. Pleon spinose cuticula: (1) absent; (2) present

20. Epimeral plate 3 posteroventral corner: (1) not produced; (2) slightly produced; (3) strongly produced and pointed

21. Epimeral plate 2 posteroventral corner: (1) not produced; (2) slightly produced; (3) strongly produced and pointed

22. Epimeral plate 1 posteroventral corner: (1) not produced; (2) slightly produced; (3) strongly produced

23. Epimeral plates 1-3 midlaterally: (1) not produced; (2) strongly produced

24. Epimeral plate 3 posterolateral margin: (1) not produced; (2) slightly produced; (3) strongly produced and pointed

25. Epimeral plate 2 posterolateral margin: (1) not produced; (2) produced

26. Epimeral plate 1 posterolateral margin: (1) not produced; (2) produced

27. Epimeral plates 1, 2, and 3 middorsally: (1) projection absent; (2) small projection; (3) long pointed projection

28. Epimeral plate 3 paired teeth on dorsal amature: (1) absent; (2) present

29. Epimeral plates 1 and 2 paired teeth on dorsal amature: (1) absent; (2) present

30. Epimeral plate 1 carinae: (1) absent; (2) present

31. Epimeral plates 2 and 3 carinae: (1) absent; (2) present

32. Pereon 1 carina: (1) absent; (2) small; (3) long and pointed

33. Pereon 2 carina: (1) absent; (2) small; (3) long and pointed

34. Pereon 3 carina: (1) absent; (2) small; (3) long and pointed

35. Pereon 4 carina: (1) absent; (2) small; (3) long and pointed

36. Pereon 5-7 carina: (1) absent; (2) small; (3) long and pointed

37. Pereon 1 dominant midlateral protrusion: (1) absent; (2) present

38. Pereon 3 and 4 dominant midlateral protrusion: (1) absent; (2) present

39. Pereon 5-7 dominant midlateral protrusion: (1) absent; (2) small; (3) long and pointed

40. Pereonite 6 spines on posterolateral margin: (1) absent; (2) present

41. Pereonite 7 spines on posterolateral margin: (1) absent; (2) present

42. Pereonites 1-4 posteroventral corner: (1) rounded; (2) pointed

43. Pereonite 5 posteroventral corner: (1) rounded; (2) pointed

44. Pereonite 6 posteroventral corner: (1) rounded; (2) pointed

45. Pereonite 7 posteroventral corner: (1) rounded; (2) pointed

46. Pereonite 2: (1) shorter than pereonite 1; (2) same length or longer than pereonite 1

47. Pereonite 7 paired teeth: (1) absent; (2) present

48. Coxal plate 1-3 dorsoventral ridge on lateral surface: (1) absent; (2) present

49. Coxa 4 dorsoventral ridge on lateral surface: (1) absent; (2) present

50. Coxal plates 5 and 6 anteriodorsal ridge on lateral surface: (1) absent; (2) present

51. Coxa 7 aterioposterior ridge on lateral surface: (1) absent; (2) present

52. Coxa 5 posteroventral angle: (1) rounded; (2) pointed not produced; (3) produced and pointed

53. Coxa 6 posteroventral angle: (1) rounded; (2) pointed not produced; (3) produced and pointed

54. Coxa 7 posteroventral angle: (1) rounded; (2) pointed

55. Basis 5 posteroventral angle: (1) rounded; (2) pointed not produced; (3) pointed and produced

56. Basis 6 and 7 posteroventral angles: (1) rounded; (2) pointed not produced; (3) produced and pointed

57. Basis 5-7 posterior margin: (1) smooth; (2) sinous

58. Coxa 5 winglike acute process: (1) absent; (2) present

59. Coxal plates 1-3 lateral face: (1) smooth; (2) acute teeth present 
Appendix B (continued)

60. Coxa 4 laterally: (1) smooth; (2) acute teeth present

61. Coxa 5 and 6 lateral face: (1) smooth; (2) with acute teeth

62. Coxa 7 laterally: (1) smooth; (2) with acute teeth

63. Coxa 4 anteroventrally: (1) not produced; (2) produced

64. Coxa 4 margin midventrally: (1) rounded; (2) pointed

65. Coxa 4 posteroventral margin: (1) concav; (2) straight or convex

66. Coxa 4 posterolateral corner: (1) rounded; (2) pointed

67. Rostrum: (1) shorter than first article of Antenna 1; (2) at least reaching distal margin of first article of Antenna 1

68. Rostrum shape: (1) straight; (2) flexed

69. Antenna 1 peduncle article 1 number of processes: (1) 0 ; (2) 1 ; (3) 2 ; (4) 3 ; (5) 4 ; (6) 5

70. Antenna 1 peduncle article 2 number of processes: (1) 0 ; (2) 1 ; (3) 2 ; (4) 3 ; (5) 4

71. Antenna 2 peduncle article 3 number of processes: (1) 0 or 1 ; (2) 2 or more

72. Antenna 2 peduncle article 4 number of processes: (1) 0 or 1 ; (2) at least 2

73. Antenna 2 peduncle article 5 number of processes: (1) 0 or 1; (2) at least 2

74. Labrum: (1) entire; (2) incised

75. Mandible molar: (1) absent or reduced; (2) well developed

76. Mandibular rakers: (1) absent; (2) present

77. Mandibular body: (1) bulky; (2) elongate

78. Mandible incisor: (1) smooth; (2) toothed

79. Maxilla 1 palp: (1) two articulate; (2) three articulate

80. Maxilla 1 palp short robust setae: (1) absent; (2) present

81. Maxilla 1 palp long setae: (1) absent; (2) present

82. Maxilliped palp article 2 distally: (1) not produced; (2) produced

83. Maxille 1 palp: (1) larger than outer plate; (2) smaller than outer plate

84. Maxilla 2 outer plate: (1) broad; (2) narrow, less than 12 of inner plate

85. Maxilliped palp article 4: (1) absent or weakly developed; (2) well developed

86. Gnathopod 1 palm shape: (1) narrow; (2) wide

87. Gnathopod 2 palm shape: (1) narrow; (2) wide

88. Gnathopod 1 palm length: (1) shorter than dactylus; (2) same or longer than dactylus

89. Gnathopod 2 palm length: (1) shorter than dactylus; (2) same or longer than dactylus

90. Gnathopod 1 spines on inner curvature of dactylus: (1) absent; (2) present

91. Gnathopod 2 spines on inner curvature of dactylus: (1) absent; (2) present

92. Gnathopod 1: (1) simple or subchelat; (2) chelat

93. Gnathopod 2: (1) simple or subchelat; (2) chelat

94. Pereopod 3 and 4 merus: (1) not produced; (2) produced

95. Pereopod 5 merus: (1) not produced; (2) produced

96. Pereopod 6 merus: (1) not produced; (2) produced

97. Pereopod 7 merus: (1) not produced; (2) produced

98. Subantennal sinus: (1) absent; (2) present

The data set was prepared in DELTA, which labels the characters in binary states 1 and 2, therefore 0 is not used. The order of states does not reflect any assumptions on which state is plesiomorphic and apomorphic. 
Appendix C

Character matrix of 16 Antarctic Amphipoda and 98 characters, character states shaded are variable

\begin{tabular}{|c|c|c|c|c|c|c|}
\hline Character & 1 & 10 & 20 & 30 & 40 & 50 \\
\hline Epimeria georgia & 1222112112 & 1111211213 & 2111112112 & 2111221111 & 1111111121 & 1111111111 \\
\hline Epimeria robusta & 1212122113 & 1112211211 & 3311112112 & 2111111111 & 1111211111 & 1331111111 \\
\hline Epimeria rubrieques & 2122112112 & 1111211213 & 2111113112 & 2333331121 & 1111111222 & 2311111211 \\
\hline Epimeria similis & 2122122113 & $111 \frac{1}{2} 211213$ & 3321113112 & 2112331231 & 1111111221 & 1311331212 \\
\hline Iphimediella georgia & 2112212222 & 1111221112 & 2113221121 & 2111111111 & 1122212111 & 1222221111 \\
\hline Iphimediella rigida & 2111212222 & 1111221113 & 2113221222 & 2111111111 & 1122212111 & 1222121111 \\
\hline Echiniphimedia hodgsoni & 2111212224 & 1112221213 & 3123111112 & 2111111112 & 2222211121 & 1111222122 \\
\hline Echiniphimedia waegeli & 1111112224 & 1111221213 & 3123111112 & 2111111112 & 2222211212 & 2222222122 \\
\hline Gnathiphimedia mandibularis & 2211222221 & 1111212213 & 2113221221 & 1111111111 & 1122212111 & 1222221111 \\
\hline Gnathiphimedia sexdentata & 2221212221 & 2111211113 & 2213211121 & 1111111111 & 1122212111 & 1222221111 \\
\hline Eusirus cf. perdentatus & 2112211112 & 1111111111 & 2111113112 & 2111131111 & 1122221111 & 1111221111 \\
\hline Monoculodes sp. & 1211121121 & 1111111111 & 1111111112 & 21111111111 & 1111121111 & 1111111111 \\
\hline Epimeria macrodonta & 2122122244 & 1212222212 & 2111211112 & 21122221 & & \\
\hline Epimeria rubrieques & 2122122233 & 1112222212 & 2111222112 & 21122221 & & \\
\hline Epimeria similis & $212212 \frac{1}{2} 243$ & 1212222212 & 2111211112 & 2111222221 & & \\
\hline Iphimediella georgia & 1112111243 & 1212112211 & 2111111221 & 12222222 & & \\
\hline Iphimediella rigida & 1112122232 & 1212112211 & 2111111121 & 12222222 & & \\
\hline Iphimediella cyclogena & 1112111233 & 1212112111 & 2111111221 & 12222222 & & \\
\hline Echiniphimedia echinata & 1112122243 & $1111112 \frac{1}{2} 11$ & 2111111221 & 12222222 & & \\
\hline Echiniphimedia hodgsoni & 2212211264 & 2221112211 & 2111111221 & 12222222 & & \\
\hline Echiniphimedia waegeli & 2212122243 & 1211112212 & 1111111221 & 12222222 & & \\
\hline Gnathiphimedia mandibularis & 1112122233 & 1111111112 & 21111111221 & 12222222 & & \\
\hline Gnathiphimedia sexdentata & 1112121242 & 1111111111 & 2111111221 & 12222222 & & \\
\hline Eusirus cf. perdentatus & 1121211145 & 2211222212 & $2 \frac{1}{2} 11222221$ & 11112222 & & \\
\hline Monoculodes sp. & 1111211111 & 1111222212 & 2111222121 & 111111221 & & \\
\hline
\end{tabular}




\section{References}

Adachi, J., Hasegawa, M., 1996. Model of amino acid substitution in proteins encoded by mitochondrial DNA. J. Mol. Evol. 42, 459468.

Arntz, W., Brey, T., 2001. The Expedition ANTARKTIS XVII/3 (EASIZ III) of RV Polarstern in 2000. Ber. Polarforsch. 402, 1-181.

Berge, J., Vader, W., Coleman, C.O., 1998. A cladistic analysis of the amphipod families Ochlesidae and Odiidae, with description of a new species and genus. Proceedings of the Fourth International Crustacean Congress, 239-264.

Berge, J., Boxshall, G., Vader, W., 2001. Cladistic analysis of the Amphipoda, with special emphasis on the origin of the Stegocephalidae. Pol. Arch. Hydrobiol. Proceedings of the Xth ICA.

Coleman, C.O., Barnard, J.L., 1991. Revision of Iphimediidae and similar families (Amphipoda: Gammaridea). Proc. Biol. Soc. Wash., 253-268.

Coleman, C.O., 1996. Two new amphipod species (Crustacea), Iphimediella ruffoi and Iphimediella dominici, from the Antarctic Ocean. Bol. Mus. Civ. Sor. Nat. Verona 20, 117-133.

Crame, J.A., 1999. An evolutionary perspective on marine faunal connections between southernmost South America and Antarctica. Sci. Mar. 63 (1), 1-14.

Cunningham, C.W., 1997. Can three incongruence tests predict when data should be combined? Mol. Biol. Evol. 14, 733-740.

Dallwitz, M.J., Paine, T.A., Zurcher, E.J., 1997. User's Guide to the DELTA System: A General System for Processing Taxonomic descriptions.

De Broyer, C., Jazdzewski, K., 1993. Contribution to the marine biodiversity inventory. Checklist of the Amphipoda (Crustacea) of the Southern Ocean. Institut royal des Sciences Naturalles de Belgique Bruxelles, Belgien: Studiedocumenten van Het K.B.I.N.

De Broyer, C., Chapelle, G., Duchesne, P.A., Munn, R., Nyssen, F., Scailteur, Y., van Roozendael, F., Dauby, P., 2001. Structural and Ecofunctional Biodiversity of the Amphipod Crustacean Benthic Taxocoenoses in the Southern Ocean. Belgian Research Programme on the Antarctic Scientific Results of Phase III (19972000). Federal Office for Scientific, Technical and Cultural Affairs, Brussels, 1-60.

Englisch, U., 2001. Analyse der Phylogenie der Amphipoda (Crustacea, Malacostraca) mit Hilfe von Sequenzen des Gens der RNA der kleinen ribosomalen Untereinheit. Dissertation, Ruhr-Universität Bochum, Lehrstuhl für Spezielle Zoologie1-312.

Folmer, O., Black, M., Hoeh, W., Lutz, R., Vrijenhoek, R., 1994. DNA primers for amplification of mitochondrial cytochrome $c$ oxidase subunit I from diverse metazoan invertebrates. Mol. Mar. Biol. Biotechnol. 3, 294-299.

Hall, T.A., 1999. BioEdit: a user-friendly biological sequence alignment editor and analysis program for Windows 95/98/NT. Nucleic Acids Symp. Ser. 41, 95-98.
Held, C., 2000. Phylogeny and biogeography of serolid isopods (Crustacea, Isopoda, Serolidae) and the use of ribosomal expansion segments in molecular systematics. Mol. Phylogenet. Evol. 15, 165178

Held, C., 2003. Molecular evidence for cryptic speciation within the widespread Antarctic crustacean Ceratoserolis trilobitoides (Crustacea, Isopoda). In: Huiskes, A.H.L., Gieskes, W.W.C., Rozema, J., Schorno, R.M.L., van der Vies, S.M., Wolff, W.J. (Eds.), Antarctic Biology in a Global Context. Backhuys Publishers, Leiden, pp. 135-139.

Huelsenbeck, J.P., Crandall, K.A., 1997. Phylogeny estimation and hypothesis testing using maximum likelihood. Annu. Rev. Ecol. Syst. 28, 437-466.

Huelsenbeck, J.P., Ronquist, F., 2001. MRBAYES: Bayesian inference of phylogenetic trees. Bioinformatics 17, 754-755.

Knowlton, N., Weigt, L.A., 1998. New dates and new rates for divergence across the Isthmus of Panama. Proc. R. Soc. Lond. B 265, 2257-2263.

Maddison, W.P., Donoghue, M.J., Maddison, D.R., 1984. Outgroup analysis and parsimony. Syst. Zool. 33, 83-103.

Meyran, J.C., Monnerot, M., Taberlett, P., 1997. Taxonomic status and phylogenetic relationships of some species of the senus Gammarus (Crustacea, Amphipoda) deduced from mitochondrial DNA sequences. Mol. Phylogenet. Evol. 8, 1-10.

Posada, D., Crandall, K.A., 1998. Modeltest: testing the model of DNA substitution. Bioinformatics 14 (10), 817-818.

Strimmer, K., von Haeseler, A., 1996. Quartet puzzling: a quartet maximum likelihood method for reconstructing tree topologies. Mol. Biol. Evol. 13, 964-969.

Swofford, D.L., 2002. Paup*.Phylogenetic Analysis using Parsimony (*and other methods). (Version 4.10 beta). Sinauer Associates, Sunderland, MA

Thompson, J.D., Higgins, D.J., Gibson, T.J., 1994. CLUSTAL W: improving the sensitivity of progressive multiple sequence alignment through sequence weighting, positions-specific gap penalties and weight matrix choice. Nucleic Acids Res. 22, 4673-4680.

Wakabara, Y., Serejo, C., 1999. Amathillopsidae and Epimeriidae (Crustacea, Amphipoda) from bathyal depths off the Brazilian coast. Zoosystema 21, 625-645.

Wares, J.P., 2001. Patterns of speciation inferred from mitochondrial DNA in North American Chthamalus (Cirripedia: Balanomorpha: Chthamaloidea). Mol. Phylogenet. Evol. 18 (1), 104-116.

Watling, L., Thurston, M.H., 1989. Antarctica as an evolutionary incubator: evidence from the cladistic biogeography of the amphipod Family Iphimediidae. In: Crame, J.A. (Ed.), Origins and Evolution of the Antarctic Biota. Geological Society Special Publication No. 47, 297-313.

Whiting, M.F., 2002. In: DeSalle, R., Wheeler, W.C., Giribet, G. (Eds.), Molecular Systematics and Evolution: Theory and Practice. Birkhauser, Basel, pp. 69-84. 